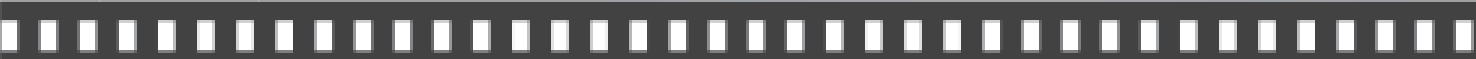

\author{
Entrevista: \\ Pedro José Martinelli
}

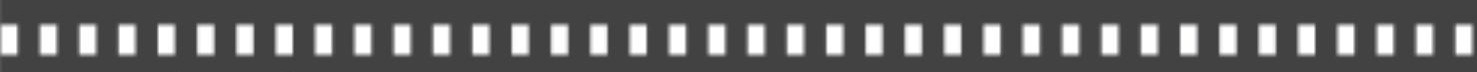

Paulo César Boni 


\title{
Um caboclo que gosta de bater pernas: o fotógrafo e cidadão Pedro Martinelli
}

A country man wholikes to wander around: the photographer and citizen Pedro Martinelli

\author{
Paulo César Boni*
}

Prestes a comemorar 50 anos de fotografia, Pedro Martinelli transita com desenvoltura pelo fotojornalismo, fotografia de moda, esportes, beleza e publicidade. Começou no fotojornalismo, em 1967, na Gazeta Esportiva, passou pelo Diário do Grande $A B C$, pelo $O$ Globo e pela revista Veja, antes de assumir a direção do Estúdio Abril, em 1984. Dirigiu o estúdio até 1995, preparando e chefiando fotógrafos e fotografando para revistas especializadas, como Placar e Quatro Rodas, e de comportamento, como Capricho e Playboy. "Os tempos de Estúdio Abril foram ótimos para treinar o olhar. Aprendi muito sobre moda, beleza e harmonia", declara. Entre 1995 e 2005, dedicou-se a projetos pessoais de documentação fotográfica no Norte do Brasil, dos quais resultaram os livros Amazônia: o povo das águas e Mulheres da Amazônia.

Hoje, com a experiência que acumulou e a sabedoria da maturidade, não hesita em afirmar que sua fotografia é um retrato de sua formação cidadã, especialmente a convivência familiare os ensinamentos dos irmãos Cláudio e Orlando Villas-Bôas, sertanistas com quem conviveu por três anos na Amazônia. "Essa experiência ajudou a formatar meus conceitos de respeito, caráter, educação, cultura, família e vida". Pedro Martinelli se define como uma pessoa simples: "um caboclo que gosta de bater pernas". Essa, aliás, é a dica que dá aos fotógrafos: bater pernas. "Quando o cara bate pernas, a missão está cumprida", ensina.

* Doutor e pós-doutorando em Ciências da Comunicação pela Universidade de São Paulo (USP). Professor do Departamento de Comunicação da Universidade Estadual de Londrina (UEL). Coordenador do Curso de Especialização em Fotografia: Práxis e Discurso Fotográfico. Email: pcboni@sercomtel.com.br 


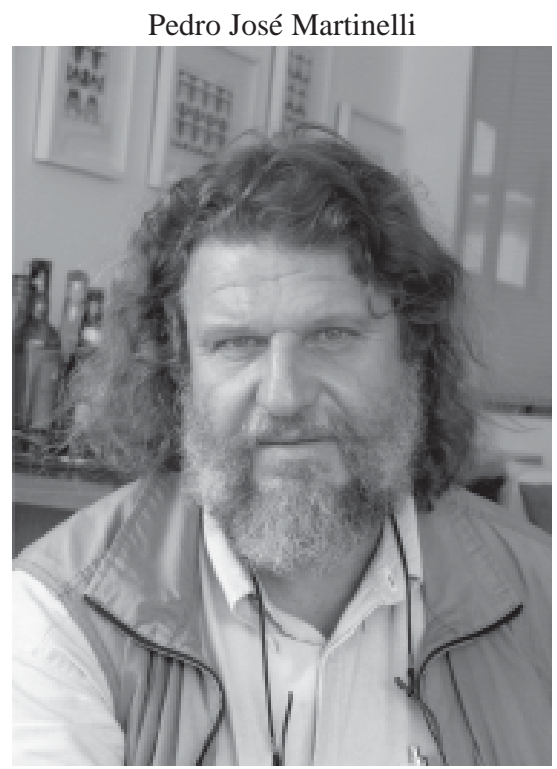

Fotografia: Renata Barbosa de Oliveira

\section{Entrevista}

Paulo Boni - Pedro, bom dia! Desculpe a formalidade, mas, considerando que alguns de nossos leitores podem, ainda, não conhecêlo, vou tomar a liberdade de começar pela sua trajetória profissional. Você começou a trabalhar na Gazeta Esportiva, certo?

Pedro Martinelli - Sim, a Gazeta Esportiva era um jornal de esportes importante de São Paulo, que mais tarde passou a pertencer ao Grupo Folha [da Folha de S. Paulo] e, tempos depois, desapareceu.

Paulo Boni - Depois da Gazeta você foi para o Diário do Grande $A B C$, em 1961 ?

Pedro Martinelli - Na verdade, eu comecei na Gazeta por acaso. Mas foi lá que eu tive contato com a fotografia, foi lá que eu aprendi a fotografar, foi lá que eu comecei a ver a fotografia como fotógrafo. Eu era um aprendiz de fotógrafo na Gazeta Esportiva em Santo André, minha 
cidade. Depois fui para um jornal semanal que se chamava News Seller, que em seguida virou diário, o Diário do Grande ABC. O News Seller era um semanário, fundado em 1958, por quatro jovens, que cresceu acompanhando o desenvolvimento econômico daquele período. Foi ele, inclusive, quem cunhou o termo $\mathrm{ABC}$ para designar a região. Esse jornal era distribuído gratuitamente, uma inovação para a época, mas era um jornal importante na região do ABC. Em 1968, o News Seller virou Diário do Grande $A B C$. Bom, eu trabalhei no News Seller, fiz a passagem para o Diário, e depois eu fui para $O$ Globo.

Paulo Boni - No jornal O Globo você ficou de 1970 a 1975 ?

Pedro Martinelli - Isso, de 1970 a 1975. Depois eu recebi uma proposta para trabalhar com o Paulo Egydio Martins, que havia sido eleito governador de São Paulo. Eu o conheci na Fotokina, em 1962, na Alemanha. Eu havia ganho o Concurso Realidade de Fotografia, da revista Realidade, e o prêmio era uma viagem para a Alemanha. Foi lá que ele me conheceu pessoalmente, mas ele já conhecia o meu trabalho, principalmente a cobertura que fiz para $O$ Globo dos índios gigantes, e gostava da minha fotografia. Ele conhecia o trabalho do pessoal da ENFOCO, inclusive, fazia um curso na escola. Eu também estava nesse grupo. Por lá passaram vários fotógrafos, a ENFOCO era um importante núcleo de discussão da fotografia e foi uma escola que formou bons fotógrafos brasileiros. Nessa altura, eu já era um fotojornalista profissional, mas circulava e colaborava com a escola, eu era uma espécie de monitor de laboratório e falava sobre minha experiência no fotojornalismo. Quando o Paulo Egydio assumiu o Governo de São Paulo me convidou para trabalhar com ele no governo. A proposta era ótima. A ideia era cobrir o cotidiano do governador e fornecer imagens exclusivas para a imprensa, como fazia o fotógrafo do Kennedy ${ }^{1}$ ou seja, fotografar o governador no dia-a-dia, com a família, nas viagens e coisas desse gênero. Além disso,

John Fitzgerald Kennedy (1917-1963) foi eleito o $35^{\circ}$ presidente dos Estados Unidos da América no final de 1960. Tomou posse dia 20 de janeiro de 1961 e governou até 22 de novembro de 1963, quando foi assassinado na cidade de Dalas, no Texas. 
trabalhar na recuperação da memória do Estado de São Paulo, fotografando as antigas fazendas de café. Fiquei um ano e meio nesse trabalho, mas acabei voltando para as ruas.

Paulo Boni - Esse período foi entre 1975 e 1976 ?

Pedro Martinelli - Isso. Na verdade, nem deu dois anos completos, pois, no meio de 1976 eu já comecei a fazer alguns freelances para a Veja, com o Darcy Trigo, que era o chefe de fotografia da revista, e o Sérgio Sade, que era fotógrafo. O Darcy Trigo era muito amigo do meu chefe no Rio de Janeiro, o Erno Schneider, que fez aquela fotografia emblemática do presidente Jânio Quadros com os pés trançados e, por indicação do Schneider, o Trigo me convidou para uns freelances na Veja. Só recentemente, quando li a entrevista do Sérgio Sade na revista Discursos Fotográficos, fiquei sabendo que a minha ida para a revista já vinha sendo planejada entre o Trigo e o Sade. Bom, o fato é que eles me chamaram e eu fui. Permaneci na Veja, vamos dizer, assim, oficialmente registrado, de 1976 a 1984.

Paulo Boni - Perfeito! E aí, na sequência?

Pedro Martinelli - Daí, na sequência, eu fui para um cargo de chefia de fotografia no Estúdio Abril, onde permaneci de 1984 a 1995, ano em que saí da Abril.

Paulo Boni-Que tipo de trabalho você fazia na chefia do Estúdio Abril? Qual era exatamente a sua função?

Pedro Martinelli - Bom, o convite para eu ir para o Estúdio Abril foi uma proposta inédita para um fotojornalista recém-saído da Veja. Foi uma coisa completamente inusitada. Eu saí da Veja, que era um mundo à parte, e entrei no estúdio, que era uma coisa genial, pois ele trabalhava direta ou indiretamente com todas as outras revistas do Grupo Abril. Foi um choque de postura, vamos dizer assim, mas foi muito bom porque eu aprendi muito sobre fotografia; a minha vida mudou, a fotografia passou a ter uma abrangência muito maior. Foi um começo difícil para ambas as 
partes, pois tivemos que nos alinhar, mas, depois de algum tempo, passamos a nos entender muito bem. Explico. É que o estúdio era um prestador de serviços para as revistas da Editora Abril, ele tinha autonomia e cobrava pelos serviços dos seus fotógrafos, era como se houvesse uma agência dentro do estúdio, uma agência de fotógrafos especializados em estúdio. E, de repente, um cara estranho, um fotojornalista, passa a chefiálo. Precisamos de algum tempo para nos ajustarmos, mas, no fim, tudo acabou bem.

Paulo Boni - Muitas mudanças...

Pedro Martinelli - Sim, muitas mudanças, e em altíssima velocidade. Passamos de um kart para um carro de Fórmula 1, vamos dizer assim.

Paulo Boni - Foi nessa experiência do Estúdio Abril que você enveredou para a fotografia de moda?

Pedro Martinelli - Sim, nesse período de 11 anos de Estúdio Abril eu transitei pela fotografia de moda, beleza, decoração, nus para a Playboy e mais um monte de coisas. Foi uma delícia fazer tudo isso, porque eu queria mesmo fazer, queria aprender mais, minha fotografia mudou bastante, passei a enxergar coisas que eu não enxergava, enfim foi ótimo; uma coisa que me ajudou muito foi trabalhar com fotografia publicitária, que, até então, eu nunca havia feito. Comecei a fazer fotografias para propaganda no Estúdio Abril. Fotografei para praticamente todas as revistas do Grupo Abril, mas continuei fazendo fotojornalismo para a Veja, cobri Copas do Mundo, Olimpíadas. Eu era uma espécie de "peão" da fotografia, vamos dizer assim, sempre tive esse perfil de andarilho.

Paulo Boni - O Estúdio Abril passou a ter a "cara" do Pedro Martinelli?

Pedro Martinelli - Não, sem exageros. O problema é que eu sou um cara muito inquieto e estou sempre promovendo mudanças. Quando eu cheguei, o estúdio tinha três fotógrafos contratados. Esse número passou 
para 11, porque o próprio estúdio começou a formar fotógrafos e absorver essa mão-de-obra especializada. Os melhores assistentes do Estúdio Abril são hoje belos fotógrafos do mercado. O estúdio foi uma ótima escola de fotografia, formou muita gente boa. Ele tinha especialistas em diversos segmentos da fotografia: moda, carro, decoração. As revistas podiam escolher o fotógrafo que quisesse para fazer o trabalho. Era o cliente que escolhia o fotógrafo e não o estúdio que impunha um fotógrafo ao cliente. Sempre havia uma negociação, o estúdio era como se fosse o mercado. O cliente reservava o estúdio e escolhia o fotógrafo e nós, claro, cobrávamos por esses serviços, tinha tabela de preços, tinha nota fiscal, tinha toda a burocracia que tem uma empresa. Quando um fotógrafo ia cobrir algum evento esportivo para alguma revista do grupo, a revista tinha que pagar ao estúdio pelos meus serviços, como se fosse um freelancer. Eu, por exemplo, cobri três Copas do Mundo e duas Olimpíadas para a Placar e a revista pagou ao estúdio pelos meus serviços. Por questões burocráticas, passei a fotografar para a Placar como contratado da revista. Cheguei, inclusive, a ser editor da Placar durante um período, mas continuava sendo do estúdio. Era uma delícia, gostei muito desse tempo.

Paulo Boni - E quando você trocou esse glamour todo pela Amazônia?

Pedro Martinelli - Em 1995, meu cargo no Estúdio Abril era gerente de serviços fotográficos. Três departamentos eram subordinados a essa gerência: o estúdio fotográfico, os laboratórios e os equipamentos fotográficos, e o acervo fotográfico. Todos eram enormes. O estúdio atendia as demandas de todas as revistas do Grupo Abril. Os dois laboratórios também eram enormes, um deles tinha 15 funcionários e atendia todo o material produzido pelo estúdio, ou seja, revelava algo em torno de 30 a 35 mil filmes por mês. O outro laboratório, praticamente, só atendia as demandas da revista Veja, mas também era enorme, tinha 14 funcionários. Esses dois laboratórios, o estúdio e o acervo fotográfico estavam sob minha responsabilidade. Era um punhado de gente: fotógrafos, 
assistentes, laboratoristas, eletricistas, marceneiros, secretárias etc. O estúdio era anexo à cozinha experimental da revista Cláudia, o que gerava um volume muito grande de pessoas circulando por ali, era uma mini Hollywood, uma loucura, mas muito interessante...

Paulo Boni - Desculpa, Pedro, mas você se empolgou falando da estrutura fotográfica da Editora Abril e acabou não completando porque saiu do estúdio...

Pedro Martinelli - Eu já ia chegar lá. É que inverti tudo, ou seja, antes de dizer porque saí, decidi justificar a minha saída. Mas já estou chegando lá. É que mudaram a minha função, eu passei a ser diretor de serviços fotográficos, além de assumir outras funções em outras áreas. Mas, enfim, eu continuava viajando e fotografando sem parar. Mas, claro, eu tinha estrutura para isso. Eu tinha uma gerência que me ajudava muito, eu tinha o pessoal da administração, que cuidava de toda a parte burocrática para mim, eu tinha as secretárias, enfim, era uma estrutura bem montada, que me permitia continuar viajando e fotografando, condição sine qua non para eu continuar na Abril. Ao longo dos 11 anos que trabalhei no Estúdio Abril fiquei matutando: ou o estúdio seria a minha última parada, ou seja, eu ficaria definitivamente na Abril, ou iria para o mercado, o desafio que ainda me faltava, e realizaria meus projetos pessoais. Em 1995, decidi que era hora de sair, e saí. A primeira coisa que eu fiz foi ir para a Amazônia, comprei um barco e fui fazer Amazônia: o povo das águas ${ }^{2}$, mas, claro, continuei fazendo muitos freelances para a Editora Abril, como fotógrafo independente.

Paulo Boni - A informação que tínhamos é que você ficava seis meses na Amazônia, cuidando de seus projetos pessoais, e passava os outros seis meses trabalhando em São Paulo para arrecadar dinheiro e sustentar seus projetos pessoais. É isso mesmo?

2 Título de um dos livros de Pedro Martinelli, lançado pela Editora Terra Virgem, em julho de 2000 . 
Pedro Martinelli-Mais ou menos isso. Eu fazia assim: quando eu tinha trabalho por aqui [São Paulo] eu vinha fazer, quando não tinha eu ia para o Amazonas. Essa era minha vida. Na verdade, eu não podia ficar mais que dois meses no Amazonas por causa dos filmes, pois eu já tinha feito todos os testes e os filmes não aguentavam o clima úmido por mais de dois meses. Eu precisava vir para São Paulo, de vez em quando, para revelar os filmes. Não valia a pena correr o risco de perder o trabalho de 30, 40, 50 dias de trabalho, deixando os filmes armazenados no barco, com quase $100 \%$ de umidade, era muita responsabilidade, entendeu? Então eu voltava para revelar os filmes, trabalhava um pouco aqui e em seguida voltava para lá, afinal, meu projeto pessoal no Amazonas era muito bem estruturado, eu fui para lá muito bem informado e estruturado, pensei nesse projeto durante dez anos.

\section{Paulo Boni - Planejou isso tudo?}

Pedro Martinelli-Sim, tudo muito bem planejado. Como eu disse, foi um projeto durante dez anos, tudo o que você pode imaginar em termos de logística, dinheiro, o que e quando fotografar, tudo foi pensado e pesquisado com antecedência. Quando eu fui para lá eu já fui sabendo tudo o que eu faria, onde e quando faria. Lá, você precisa fotografar os temas de acordo com a época em que é possível fazer isso, você não pode navegar 40, 60, 80 horas para chegar ao local e perder a viagem. Eu comecei fotografando a juta; foi o primeiro tema que fotografei. Para tanto, eu fui para a Várzea do Solimões, onde ela é plantada, e cheguei na época exata da colheita. Você precisa saber disso tudo com antecedência, senão chega lá e perde a viagem. AAmazônia não permite nenhum tipo de erro de estratégia. Pessoas como nós não têm a menor ideia do que é a Amazônia. Por isso eu fiquei dez anos pensando e planejando, mentalizando o projeto, estudando, lendo, conversando, sonhando com ele, mas quando eu cheguei lá dei de cara com aquilo que eu queria. Para fazer a fotografia de capa do Amazonas: o povo das águas, eu passei dez dias na Várzea do Solimões, mesmo estando no lugar certo e na hora certa. Todos os dias eu acompanhava os trabalhadores que saíam às quatro horas da 
madrugada para os alagadiços, passavam o dia todo trabalhando, às vezes, com o corpo cheio de sanguessugas. Mas quando voltávamos eu sabia que tinha voltado com um belo material, entendeu? Depois da juta eu fui atrás do pau-rosa. Passei meses fotografando o pau-rosa. É óbvio que você sempre aproveita e fotografa, também, o que vem pelos lados, mas eu não desviava meu foco do pau-rosa. Eu ia nele, entendeu? E assim eu fui, trabalhando por temas. Esse é o segredo. Você tem que se planejar para trabalhar por temas, se não acaba se atrapalhando, e a cada tema que eu fotografava eu voltava para São Paulo, revelava os filmes, analisava o que eu tinha feito, avaliava os erros que havia cometido, (re)conversava comigo mesmo, revia o planejamento e voltava com oxigênio renovado para dar continuidade ao projeto. E, claro, nesse meio tempo eu aproveitava para fazer alguns trabalhos para a Editora Abril. Eu estou falando assim, meio drasticamente, porque, de fato, as pessoas não entendem como é, eu falo isso a vida inteira e ninguém entende.

Paulo Boni - Esses seus projetos pessoais na Amazônia foram de 1995 até quando?

Pedro Martinelli - Isso não acabou. Os projetos continuam até hoje. O primeiro livro, Amazônia: o povo das águas, demorou seis anos para ficar pronto. Cinco anos navegando e fotografando e mais um ano no processo de edição. Eu comecei em 1995 e o livro só foi lançado em 2000.

Paulo Boni - E o segundo livro, Mulheres da Amazônia, quando foi lançado?

Pedro Martinelli - Em 2004. Esse saiu mais rápido porque eu já tinha algum material produzido. Mesmo assim, foram três anos fotografando para produzi-lo. Eu descobri, por exemplo, mulheres trabalhando na usina hidrelétrica de Tucurui, no Rio Tocantins, e fui lá especialmente para fotografá-las; eu tinha as marisqueiras da Ilha de Marajó, e fui lá para fotografá-las. Peguei os temas que precisava desenvolver e fui tocando o projeto, entendeu? 
Paulo Boni - Então, a Amazônia continua a ser um projeto?

Pedro Martinelli - Não, agora não é mais um projeto. Agora a Amazônia faz parte de um bolão, de um projeto maior. Eu não tenho, nesse momento, um projeto específico para a Amazônia, mas ela entra como coadjuvante nos projetos que eu penso atualmente.

Paulo Boni - Bom, até agora, estruturamos sua trajetória profissional, passando por jornais, revistas, o Estúdio Abril, os projetos pessoais na Amazônia, os livros. Para encerrar definitivamente esta parte, eu queria perguntar algo chato: financeiramente, você vive da fotografia?

Pedro Martinelli-Sim. Eu continuo fotografando, faço uma coisa aqui outra coisa ali e vou vivendo. Houve um tempo em que vivi do bom e velho jornalismo. Além de ganhar com o jornalismo, ele tinha volume, me ajudou a fazer os livros. O jornalismo nunca foi assim, vamos dizer, maravilhoso, de pagar todas as contas, mas sempre tinha trabalho. Eu vendia matérias, eu propunha reportagens. Eu colocava a pauta embaixo do braço e ia na Veja vender a matéria. Brigava, discutia horas com o diretor da revista, que queria pagar metade do que eu pedia, era uma discussão tenebrosa, mas sempre saía alguma coisa. De 1998 para cá, o jornalismo foi morrendo, está praticamente morto, não existe mais. Meu telefone não toca mais, e nem vai tocar, pois o jornalismo não existe mais. Para não dizer que o sonho do jornalismo não existe mais, de vez em quando tem algum soluço. Em setembro de 2013, a Veja completou 45 anos de circulação e eles lembraram do contato que eu havia feito com os índios gigantes na região amazônica, há 40 anos. Me contrataram e eu fui lá reencontrar meu personagem. Levei-o ao local onde o havia fotografado na década de 1970, onde hoje funciona um supermercado, e fotografei-o novamente. A Veja fez uma história, usou as duas fotografias, mas isso foi uma raridade... Tocar o telefone e alguém te chamar para fazer um editorial, nem pensar. Isso não existe mais.

Paulo Boni - Se me permite, quero retomar algumas coisas do passado, como aquela aventura que você teve com os irmãos Cláudio e 
Orlando Villas-Bôas na Amazônia. Resumidamente, como você classificaria - ou conceituaria - sua experiência sertanista com os irmãos Villas-Bôas?

Pedro Martinelli-Bom, essa foi a maior de todas as experiências da minha vida, sob todos os aspectos. Essa experiência ajudou a formatar meus conceitos de respeito, caráter, educação, cultura, família e vida. Eu já vinha sendo preparado pela minha família para ser um homem que respeitasse a natureza. Eu nasci dentro desse universo. Meu avô e meu pai eram caçadores, eu sempre senti o cheiro de mato nas roupas do meu pai. Meu pai participava de uma turma de caçadores e, como ele era açougueiro, o couro do veado era tirado na minha casa, a repartição da caça era feita na minha casa, a comemoração, a comida, o jantar, o vinho, tudo era na minha casa. O padre que rezava a missa aos domingos vinha tomar vinho e saborear pratos de caça na minha casa, entendeu? Minha vida, na cidade de Santo André era a igreja e minha casa. Minha mãe tocava órgão na igreja. Os padres eram italianos e vinham à minha casa para ouvir histórias de caçadas. Minha casa era a fotografia que faço hoje. Se eu falar para você que sofri influência desse ou daquele fotógrafo é pura bobagem. Minha influência veio dessa convivência, dessa época, dessa visão de mundo, da família, da amizade, das figuras humanas, de meu pai, com uma faca na mão, tirando o couro do veado, aquela habilidade, o brilho da faca... Isso é a minha fotografia. O meu universo é esse: o mato, a floresta, os bichos, os objetos, as expressões dos caboclos, a luz, aquelas coisas que eu gosto. Enfim, quando eu cheguei lá na Amazônia eu dei de cara com o Cláudio e com o Orlando Villas-Bôas, que eram caboclos iguais ao meu pai e a minha mãe; a conversa era a mesma e foi uma maravilha porque sedimentou minha conduta. Foi na hora certa, na hora que mais precisava, eu tinha 20 anos, a idade em que as coisas se sedimentam no ser humano. Eles eram como o meu pai, o cara que me ensinou a andar no mato, a dar o tiro, me ensinou tudo. O Cláudio me deu uma visão de Amazônia, me localizou a Amazônia no universo. Eu comecei a entender o que era índio, nunca tinha visto um índio e fui viver com 20 índios maravilhosos do Xingu. Com 20 anos, me senti valorizado como 
gente, procurei entender a importância da Amazônia, da terra, da natureza. Aquilo entrou na minha alma, você não faz ideia de como eu fiquei enlouquecido, aquilo foi inesquecível. Meu contato com os índios foi muito emblemático, e simbólico. Eu estava começando a fotografar, eu ainda era um imbecil, sabia muito pouca coisa, e, ao mesmo tempo, era hábil com uma câmera fotográfica nas mãos, porque acertar a medição da luz, sem fotômetro, e conseguir foco no meio da mata, com os personagens em movimento, era difícil, mas eu consegui, sem que ninguém me ensinasse nada. Como eu consegui? Essa é uma pergunta meio complicada, que até hoje eu não sei responder. Como acertei a luz no meio da mata? Foi um instinto, um comando? Sei lá. O interessante é fazer as coisas com emoção. Eu apertava o botão emocionado, sob muita emoção, tomando o partido do Cláudio e, ao mesmo tempo, ouvindo a "cabeça" dele, o que ele achava da vida, do Brasil, dos militares. Para mim, tudo aquilo foi uma coisa espetacular.

Paulo Boni - Uma escola?

Pedro Martinelli - A melhor de todas as escolas, uma escola de vida.

Paulo Boni - Por falar em escola, você tem algum curso de graduação?

Pedro Martinelli - Não. Eu não tenho nada. Fiz o colégio e me mandei para o mato.

Paulo Boni - Nessa sua temporada amazônica você fotografou os índios gigantes, os krenakarore, hoje conhecidos como panarás. Qual foi sua sensação ao fotografar, pela primeira vez, índios até então nunca vistos?

Pedro Martinelli - Na verdade, isso foi um conjunto de coisas. Foram três anos desde o dia que em que cheguei lá até o dia em que eu fiz a fotografia. Eu fiz a fotografia e, em seguida, cai na água; a canoa em que eu estava virou e lá foram todos os meus filmes para água. Eu queria morrer. Imagina, eu pensei que havia perdido tudo. Aquilo, para mim, era 
como encerrar a minha carreira. Eu podia ser mandado embora, ser considerado um lixo, um incompetente. Imagina, durante quase três anos o jornal me pagando, investindo em mim e, de repente, você perde todo o seu trabalho. Eu estava lá com o Luigi Mamprim, da revista Realidade, que era fotógrafo da Veja na época, imagina? Isso seria a desgraça da minha vida. Os índios pegavam meus filmes no fundo do rio com os pés e os entregavam para mim, completamente encharcados. Sem perspectiva nenhuma, enviei os filmes para o Rio de Janeiro, onde o Erno Schneider, que era meu chefe, uma pessoa maravilhosa, os revelou. Inacreditável! Apenas um filme havia manchado, um filme! Foi a minha salvação.

\section{Paulo Boni - O próprio Erno revelou os filmes?}

Pedro Martinelli - Não. O Erno chamou todos os laboratoristas do jornal e explicou a situação. Com toda a experiência que eles tinham, decidiram colocar os filmes em uma banheira com água por dez minutos, para amolecer a gelatina. Depois, desenrolaram os filmes dentro da água e colocaram-nos para revelar. Só isso. Os filmes revelados ficaram impecáveis, maravilhosos, não aconteceu nada. A "chapa” com a imagem do índio, com o qual havíamos feito o primeiro contato, não tem nenhuma mancha, nada, ficou impecável. São coisas incríveis, que não têm explicação, entende? Eu fiquei muito feliz com o resultado dos laboratoristas, pois eles salvaram as minhas fotografias. E a minha felicidade, claro, tem uma explicação: fotografar aquele índio foi um momento mágico para mim, um momento de um cara habilidoso, que não perde o "pulo do gato". O índio apareceu de repente, pulou na minha frente e, em um misto de habilidade e sorte, fotografei. A primeira fotografia que eu fiz ficou meio tremida, mas a segunda deu certo. Tem outra fotografia mais incrível ainda que eu fiz que é aquela dos índios flechando o avião. Eu enfiei a cara fora do avião, com uma lente enorme, e fiz a fotografia. Essa foi muito difícil, foi o máximo, porque tem que cuidar do foco, apertar o botão na hora certa. Gosto muito dessas duas fotografias, foi bacana, foi emocionante fazê-las, mas, a do primeiro contato com os índios krenakarore, é mais emocionante, é uma fotografia histórica. Mas, genial 
mesmo foram os três anos de convivência com os índios, as caçadas que fazíamos, os nossos medos, as histórias do Cláudio Villa-Bôas, nossas conversas... Isso foi importante para "aprumar" a minha vida, foi isso que me deu uma linha de conduta, porque eu tinha 20 anos naquela época e se um indivíduo com 20 anos firma um propósito, adota uma conduta, forja o caráter, isso é para sempre. Voltei lá onde fotografei o índio no final de 2013 e só vi desgraça. Hoje a coisa está tenebrosa. Naveguei naquele rio em que eu nadava e tinha peixes maravilhosos e ele está totalmente poluído, destruído, contaminado por mercúrio. É uma pena, é tenebroso, é desanimador. Eu vivi uma realidade e hoje a realidade é outra. Isso me entristece demais.

Paulo Boni - Lamento, por você. Lamento por todos nós.

Pedro Martinelli - Você não viu na Veja?

Paulo Boni - A edição comemorativa dos 45 anos da revista?

Pedro Martinelli - É. Inclusive, é legal você vê-la com o Ipad. Com o dedo, você passa a fotografia do primeiro contato com o índio, 40 anos atrás e, passando o dedo, vai entrando a fotografia dele, hoje, fazendo compras no supermercado construído onde, há 40 anos, era sua aldeia.

Paulo Boni - Mudanças, meu caro, mudanças... AAmazônia é um dos momentos mais importantes de sua vida?

Pedro Martinelli-É o momento mais significativo.

Paulo Boni - Podemos considerar que o período que você ficou na Veja, com o Sérgio Sade, o Carlos Namba, o Irmo Celso é outro momento importante de sua vida?

Pedro Martinelli-Nossa! Grandes nomes, grandes profissionais...

Paulo Boni - O Irmo Celso agora é meu vizinho, voltou a morar em Apucarana...

Pedro Martinelli - Ele continua fotografando? 
Paulo Boni - Só como hobby. O Irmo agora é advogado, mas é um militante de causas sociais e ambientais, então ele fotografa para conscientização de preservação ambiental, para relatórios de ONGs e coisas do gênero.

Pedro Martinelli-Ele é advogado! E exerce a profissão, de terno, gravata e tudo?

Paulo Boni - Como manda o figurino. Algum tempo atrás, promovemos um encontro surpresa do Irmo Celso com o Sérgio Sade em Londrina, no meio de uma aula do Sade na Universidade Estadual de Londrina. Foi uma cena emocionante!

Pedro Martinelli-Legal!

Paulo Boni - Bom, vamos voltar à Veja. No período que você trabalhou na revista, o Brasil era governado pelo regime militar, inclusive, o AI-5 estava vigorando. Como repórter fotográfico, você teve algum problema com o regime militar?

Pedro Martinelli - Eu tive problemas antes, no $O$ Globo. Na Veja eu também tive alguns problemas, mas não foram graves. Uma vez me pegaram quando eu estava fazendo uma fotografia da sede do DOI$\mathrm{CODI}^{3}$, mas isso já foi em uma fase mais mansa do regime. Na época do O Globo eu tive mais problemas, pois o período era de repressão brava mesmo. Lá o DOPS ${ }^{4}$ me pegou muito, quase sempre em cobertura de manifestações de ruas, levei muita porrada, mas e daí? Eu considerava isso normal, fazia parte da brincadeira, o sujeito estava lá para isso mesmo. Falando desse assunto, me lembrei de algo até engraçado. Recentemente, durante as manifestações de junho de 2013, os fotógrafos fizeram uma manifestação na Igreja da Consolação contra a violência da polícia. Eu achei engraçado, interessante, até comentei isso com alguns amigos, mas

3 DOI-CODI - Destacamento de Operações de Informações do Centro de Operações de Defesa Interna, órgão repressor criado pelo regime militar (1964-1985), que prendia e, não raro, torturava os opositores do regime.

4 DOPS - Departamento de Ordem Política e Social, órgão criado pelo governo, em 1924, para manter o controle do cidadão e vigiar as manifestações. Tinha poder de polícia e foi muito acionado durante o Estado Novo (1937-1945) e, principalmente, o regime militar (19641985), com mais autonomia e atuação mais constante entre 1964 e 1978. 
a pergunta é “como é que se controla isso, como é que resolve isso?” Eu acho que o sujeito tem que jogar com as regras do jogo. Se você vai cobrir uma jogada dessa, você está sujeito a tomar porrada, é lógico. Tem que tomar cuidado para não levar porrada, mas se levar, não pode ficar reclamando, afinal cada um está lá para manifestar, defender e brigar pelo seu ponto de vista. Eu apanhei muito, mas poderia ter evitado, poderia ter me escondido em um bar, subir no primeiro andar de algum prédio e fazer a fotografia de cima para baixo, "ficar em cima do muro", mas eu queria estar na linha de frente e, na linha de frente sempre tem porrada. Tinha uma situação que considerávamos bem engraçada: era quando os fotógrafos voltavam da cobertura de alguma manifestação e o laboratorista revelava seus filmes e fazia a folha de contato. Pela folha de contato ficava nítido quem cobriu a manifestação no front e quem se escondeu para se proteger, quem tinha coragem e quem era mais medroso ou cauteloso, quem afinou e quem não afinou. Então é isso, digamos assim, se você quiser mesmo cobrir a coisa no local e no momento do acontecimento, pode levar porrada. Faz parte do jogo, não tem conversa.

Paulo Boni - Além das porradas, você sofreu perseguições, foi preso, exilado, teve prejuízos financeiros por conta do regime militar?

Pedro Martinelli - O meu único problema era o visual. Eu sempre fui cabeludo e barbudo e, na conta deles, eu tinha cara de comunista. Então, eu tomava porrada por causa disso, antes mesmo de eu falar qualquer coisa eles já me pegavam pela barba e me jogavam dentro do camburão. Depois que eu tinha tomado um monte de porrada, que eles tinham quebrado tudo [o equipamento fotográfico], me jogavam na rua e iam embora. Eu fui fichado, mas não posso dizer que fui perseguido, entendeu? Uma vez eu havia ido a um baile e, depois que eu saí do baile, estava andando a pé pela rua e a turma do Fleury ${ }^{5}$ me pegou. Eu tinha um

\footnotetext{
Sérgio Fernando Paranhos Fleury, delegado do DOPS durante o regime militar. Tornou-se conhecido por sua obsessão em perseguir os opositores do regime e pela constante prática de tortura. Oficialmente, morreu afogado em $1^{\circ}$ de maio de 1979 , dias antes de completar 46 anos. Porém, como seu corpo não foi necropsiado, até hoje há quem diga que ele foi assassinado ou pela esquerda, como vingança pelas atrocidades que cometeu, ou pela direita, para "queima de arquivo".
} 
convite mimeografado no bolso de trás da calça, mas até você explicare eles acreditarem - que aquilo era mesmo um baile e não uma reunião de algum aparelho, eu já tinha ido em cana e tomado muita porrada. Era comum passar um ou dois dias na cadeia, mas depois eles descobriam quem eu era, que trabalhava no jornal e aí me soltavam. Depois da segunda ou terceira prisão você se tornava conhecido, era considerado "da casa" e isso facilitava um pouco a resolução dos problemas. Agora, não posso dizer que fui perseguido, que fui considerado um revolucionário, não. $\mathrm{Eu}$ era um jornalista e corria os riscos do exercício da profissão em um momento delicado, tumultuado da política brasileira.

Paulo Boni - Hoje, com total liberdade de expressão, com sua vivência e maturidade, você considera o tempo do regime militar como um período negro na história do Brasil?

Pedro Martinelli - Mas é lógico que era negro, era tenebroso. Você nunca sabia o que poderia acontecer. Tive amigos que desapareceram. Era assustador. Todo cuidado era pouco. Você tinha que tomar cuidado, é lógico.

Paulo Boni - Sempre sob tensão, né Pedro? Um momento complicado...

Pedro Martinelli-Uma noite eu tinha ido a pé até a Lapa. Naquela época eu não tinha carro e morava no Copan ${ }^{6}$. De madrugada, quando eu estava voltando, também a pé, para casa, vi um opala azul claro, era um carro da equipe do Fleury ${ }^{7}$. Imaginei que alguma coisa errada estivesse

6 Provavelmente o maior edifício residencial do país, o Copan ganhou esse nome por haver sido encomendado pela Companhia Pan-Americana de Hotéis e Turismo, em 1954, por ocasião das comemorações dos 400 anos de São Paulo. Projetado por Oscar Niemayer, sua construção começou em 1957, depois de várias adaptações no projeto original, e foi finalizada em 1966, por Carlos Alberto Cerqueira Lemes. Inaugurado em 25 de maio de 1966, na Avenida Ipiranga $n^{\circ} 200$ (Bairro Bela Vista, próximo à estação República do Metrô), tornou-se um marco da arquitetura brasileira. Hoje, cerca de cinco mil pessoas moram no Copan, que também abriga 70 estabelecimentos comerciais.

7 De acordo com o entrevistado, todos os agentes da equipe do Fleury usavam opalas azuis, facilmente identificados como "da equipe" porque tinham uma antena de rádio sobre o portamalas. 
por acontecer. Fui correndo até em casa, peguei a câmera fotográfica e voltei ao local, quando eu cheguei o dia já estava quase amanhecendo, era perto das cinco horas da manhã, e presenciei e fotografei uma morte brutal. Nessa noite, a turma do Fleury havia estourado um aparelho e matado 11 pessoas. A modalidade deles, naquela época, era chegar em silêncio, cercar a casa e pegar os caras dormindo. Antes de entrar, eles abriam fogo por todas as portas e janelas. Era uma coisa brutal, aquela artilharia de fora para dentro. Depois eles entravam e liquidavam a fatura. $\mathrm{O}$ tiroteio começou no momento em que eu cheguei quase em frente à casa [aparelho], na Rua Pio XI. Do outro lado da rua, fotografei um sujeito saindo pelo portão casa. Depois fotografei esse mesmo sujeito caído, morto, no meio da rua.

Paulo Boni - Eles não o prenderam e arrancaram o filme de sua câmera fotográfica?

Pedro Martinelli - Sim. Quando cheguei na esquina de baixo, fui preso por dois agentes que me levaram para o DOPS e, como sempre, bofetes e chutes, câmeras quebradas e rua. A essa altura, como já disse, eu já era "da casa". Eles me conheciam, sabiam quem eu era, onde eu trabalhava e me soltaram logo em seguida.

Paulo Boni - E o filme? Eles não o destruíram?

Pedro Martinelli - Sim, destruíram. Arrancaram o filme e o velaram todo, mas era um filme virgem. Quando eu comecei a descer a rua, para me afastar do local, tirei o filme sensibilizado da câmera e o substitui por um virgem. O filme que estava operado eu o joguei rente à guia [meio-fio ou sarjeta]. Joguei é modo de dizer, eu o deixei lá, o mais camuflado possível. Sempre que fazia isso, marcava bem em que altura da guia eu o havia deixado [localização espacial, em frente a alguma loja, bar ou banco, por exemplo] e, depois de passada a confusão, eu voltava ao local com o carro do jornal e tentava achar o filme deixado rente à guia. Eu aprendi a andar com um filme virgem debaixo do braço. Assim, sempre que eu fotografava alguma coisa perigosa e era abordado 
pelos policiais, mais que depressa eu tirava o filme sensibilizado da máquina e o substituía por um filme virgem. Eles vinham e arrancavam o filme, mas ele não tinha nada registrado.

Paulo Boni - E depois? Você encontrava o filme?

Pedro Martinelli - Na maior parte das vezes, eu dava a sorte de encontrá-lo, mas, algumas vezes, por um motivo ou outro, eu não conseguia recuperá-lo. Esse filme, por exemplo, eu não encontrei. Demorei um pouco mais para ser solto e, quando retornei ao local, não encontrei mais o filme. Infelizmente, tudo desapareceu, nenhuma fotografia, nada.

Paulo Boni - O Sérgio Sade falou de uma fotografia muito importante sua, do assassinato do jornalista americano Bill Stewart, na Nicarágua, que foi censurada pela Veja. Você confirma isso, ela foi censurada mesmo?

Pedro Martinelli - Sim e não. Ela foi censurada porque não foi publicada. Mas não foi culpa da Veja, e sim do Elio Gaspari ${ }^{8}$ que não quis publicar a fotografia. O Elio, aliás, era campeão dessas coisas, de autocensura, de censurar fotografias. Essa, a do corpo do jornalista Bill Stewart sendo deixado por uma camionete na frente do hotel dos jornalistas, ele achou muito chocante e censurou.

Paulo Boni - O Sade falou também que você foi o único a fazer essa fotografia...

Pedro Martinelli - Então, eu fui o único a fazer essa fotografia porque eu fui o único que ficou no hotel, eu fiquei no hotel para revelar os meus filmes, os outros jornalistas, todos, haviam saído do hotel para fazer suas reportagens. Eu tomei o café de manhã com ele no hotel...

\section{Paulo Boni - Com o Bill Stewart?}

$\overline{8}$ Elio Gaspari foi diretor-adjunto da revista Veja de 1979 a 1985. 
Pedro Martinelli - Sim, com o Bill Stewart, que era jornalista da $\mathrm{ABC}^{9}$. Durante o café ele até me convidou para ir junto com ele, porque eu falava espanhol. Eu pedi desculpas, mas disse que não poderia acompanhá-lo, pois já era sexta-feira e eu tinha que revelar os meus filmes para mandar as fotografias por telefoto para a Veja. Um amigo havia me emprestado o laboratório, que estava montado no quarto dele e eu fiquei no laboratório revelando os filmes. Meia hora depois batem no meu quarto e me avisam que um jornalista gringo havia sido morto. Eu desci correndo com a câmera e a caminhonete, com o corpo, havia chegado e estava em frente ao saguão do hotel. Um sandinista juntou o Bill Stewart pelo pescoço para mudá-lo de carro e eu fiz aquela fotografia. No fundo desta fotografia, inclusive, aparece a fotógrafa Susan Meiselas, que, chocada, não conseguiu fazer nenhuma fotografia. Eu fui o único que fez uma fotografia da chegada do corpo dele ao hotel. Depois levaram ele embora. Então, do assassinato do Bill Stewart, temos as imagens chocantes, terríveis, do cinegrafista que filmou ele sendo assassinado e a minha fotografia do cadáver chegando ao hotel, todo ensanguentado. Segundo o Sade, o Elio Gaspari disse que a minha fotografia era muito chocante e se recusou a publicá-la, alegando que ninguém "daria" uma fotografia dessas.

\section{Paulo Boni - Pena, né?}

Pedro Martinelli - Coisas do Elio Gaspari. Ele também não autorizou a publicação da fotografia do cadáver do Papa João Paulo I entrando na Catedral do Vaticano. Disse que o corpo embalsamado do Papa estava verde... Histórias do jornalismo... É assim mesmo. O motivo desse veto eu só fiquei sabendo quando de minha volta do Vaticano.

Paulo Boni - Pedro, tem mais quatro ou cinco perguntinhas para encerrarmos. Me desculpe, não entrei no seu blog recentemente, mas li um texto seu de 2011, no qual você disse ainda estar trabalhando com

ABC - American Broadcasting Company, famosa rede de televisão e rádio dos Estados Unidos. 
câmeras analógicas. Em 2014, você continua trabalhando com câmeras analógicas?

Pedro Martinelli - Não, agora eu não trabalho mais, porque ninguém mais revela os filmes. Eu tenho filmes, tenho câmera mecânica, tenho tudo, só fotografo se for para mim, coisas pessoais. Profissionalmente, nem pensar, porque no mercado profissional ninguém quer a fotografia analógica, querem somente a digital, pois a analógica dá muito trabalho, e fica cada vez mais complicado, pois você já não acha mais materiais para comprar. Não tem mais papel fotográfico no mercado, quando você acha o papel, o custo é mais alto e a qualidade do papel já não é mais a mesma: a fibra é diferente, a gramatura é diferente. Hoje nem dá mais vontade de ampliar uma fotografia em papel fotográfico, pois ele é ruim, não é a mesma coisa.

Paulo Boni - Apesar de você já haver começado a responder essa pergunta lá atrás, no início da entrevista, quero reforçá-la: como você vê o fotojornalismo brasileiro hoje?

Pedro Martinelli - Bom, o fotojornalismo brasileiro - e não só o brasileiro -, hoje, de forma geral, acabou, é zero, morreu, não existe mais.

\section{Paulo Boni - Tem como ressuscitá-lo?}

Pedro Martinelli - Não sei, é redundante, não existe. Quem pensa em viver, sobreviver disso, desista! Desista porque os jornais estão fechando, aliás, o mundo todo está acabando. Ninguém mais paga nada, ninguém quer ver, ninguém quer ler uma fotografia. Mudou muito em curto espaço de tempo, eu não sei como vai ser.

Paulo Boni - Diante desse cenário que você descreveu, vale a pena ser fotografo?

Pedro Martinelli -É muito difícil responder essa pergunta. Eu acho que tem que fazer com a fotografia o mesmo que os artistas plásticos estão fazendo: usar a fotografia como um aplicativo, a fotografia é um aplicativo para a vida. O que a maioria das pessoas está fazendo hoje em 
dia não é fotografia, é encher o saco de todo mundo com fotografia de bolo, de prato de comida, para mandar para os amigos pelas redes sociais. Desse jeito, a fotografia não tem mais a menor novidade. Agora, quem quiser fotografar mesmo, digamos assim, na essência da palavra, tem que colocar na cabeça que é muito difícil... O problema que eu vejo aqui no Brasil é que as pessoas acham que sabem, mas, na realidade, elas ainda não viram nada, não têm referências do que já foi feito e acham que o que estão produzindo é o que há. Assim não dá, fica muito difícil...

Paulo Boni - Seria, então, uma perda de referências, cada um "se acha" fotógrafo?

Pedro Martinelli-Os caras que se acham fotógrafos, nunca tiveram referências, não sabem o que aconteceu há 50, 60 anos, pensam que estão reinventando a roda. É aquela velha história: fotografia de arara. Muita gente fotografa arara há muito tempo. É tudo a mesma coisa. Imagina um rapaz que nasça hoje. Quando tiver 20 anos ele vai pegar uma câmera fotográfica e vai fotografar arara. $\mathrm{O}$ que você acha? O cara vai pegar uma câmera e vai fotografar arara de novo?

Paulo Boni - Acho que sim. De repente, ele pode fazer isso não profissionalmente, mas para vencer um desafio pessoal, uma conquista, uma necessidade de afirmação, alguma coisa nesse sentido...

Pedro Martinelli - Então, ele vai a usar a fotografia como um aplicativo. Uma contribuição dele para a sociedade daqui a 20 anos pode ser um filtro, uma textura de meia na frente da lente, um formato quadrado, sei lá, algo que acrescente alguma coisa à fotografia da arara, porque a fotografia de uma arara propriamente dita não terá nada de inédito, entendeu?

Paulo Boni - Estou tentando costurar suas falas para saber onde você pretende chegar...

Pedro Martinelli -É simples. Eu quero dizer que se todo mundo sair aí pelo mato fotografando bicho, ninguém mais aguentará ver tanta 
fotografia igual de arara ou onça, vai ficar tudo banalizado, será igual fotografia de prato de comida no Instagram. Os caras ficam fotografando pratos de comida, gatos, o cara sobe no avião e faz uma fotografia, acho que agora estão chamando de selfie, e faz uma fotografia da janela, mostrando a asa do avião, outra mostrando o céu. Será que eles não se dão conta de que isso é ridículo, de que estão enchendo o saco de todo mundo? Para que serve esta fotografia? O próprio cara não sabe, ele não quer ou não pode perder tempo perguntando "para que serve isso que eu estou fazendo?". Na realidade, tudo começa com essa pergunta: "para que serve isso que eu estou fazendo?'. Qual é a utilidade disso? Se não tem utilidade nenhuma, se, jornalisticamente, não tem peso nenhum, então não é fotografia, é um aplicativo. Aí, o cara fala: "Eu sou um fotógrafo de arte", ou seja, ele ainda se considera um artista e quer que os outros vejam e gostem de sua "arte".

Paulo Boni - Nossa, Pedro! Você não está sendo dramático demais?

Pedro Martinelli - Talvez, mas se não tomarmos cuidado, esse será o fim da fotografia. No entanto, eu ainda acredito em algumas saídas, principalmente a da fotografia de documentação. Documentar com critério e seriedade seu espaço, seu dia-a-dia, contar a história de um lugar, de um povo, de uma profissão, é para isso que a fotografia serve, para documentar. Se você usar a fotografia para contar uma história, de preferência alguma coisa inédita, algum tema que ainda não tenha sido abordado, aí sim ela tem um importante papel social. Agora, se você se mete a fotografar arara, meu caro, você tem que fazer uma pesquisa enorme para saber tudo o que já foi fotografado, para saber se o seu ponto de vista será inédito ou se será apenas mais uma fotografia de arara. Se você simplesmente pegar uma câmera e sair por aí fotografando arara, me desculpe, mas é perda de tempo, é burrice. É a mesma coisa um cara ir para a Índia, fotografar e pôr suas fotografias nas redes sociais, pode ser uma satisfação pessoal para ele, mas suas fotografias não servem para nada, é zero, porque tem bilhões de fotografias da Índia disponíveis, muito 
melhores que as dele, mas que ele nem sabe da existência. Fotograficamente falando, é melhor o cara ir para Itapecerica da Serra fazer um ensaio ou um documentário sobre Itapecerica da Serra, porque se ele for para o Rio de Janeiro, vai perder seu tempo, pois existem três milhões de clichês ótimos sobre o Rio de Janeiro, não é mais novidade para ninguém. Um sujeito com um revólver na mão, apontando para a câmera, falando palavrão, cadê a novidade disso? Ninguém mais aguenta fotografias e filmes retratando a violência do Rio de Janeiro... É tudo a mesma coisa.

Paulo Boni - Então, a melhor solução para a fotografia é o ineditismo?

Pedro Martinelli -Pois é, você entendeu o caminho da fotografia? Precisa ficar quieto, falar pouco, ler e pesquisar muito. Ainda existem possibilidades de se fazer algumas coisas boas, mas todas dependem de muito estudo e planejamento. Hoje em dia, tudo muda muito rápido, você precisa estar preparado para estar no meio de um projeto e, de repente, precisar mudá-lo. Olha, quando eu estava fazendo o meu livro...

\section{Paulo Boni - Qual deles?}

Pedro Martinelli - Amazônia, o povo das águas. Eu o tinha planejado antes de viajar para a Amazônia, eu fiz uma pesquisa enorme, mas tive que adaptá-lo diversas vezes, pois coisas novas apareciam a cada dia e eu também cheguei à conclusão que algumas coisas eu não conseguiria ver, como por exemplo, um sujeito arpoando um pirarucu. Hoje tem, mas aquele tempo não tinha. Eu pesquisei toda a literatura e não encontrei. Só vi essa cena em um documentário de um cineasta português que vivia na Amazônia, o Silvino Santos, na qual um pirarucu arpoado saiu arrastando a canoa do pescador. Depois aparecia a cena daquele monte enorme de pirarucus em uma praia gigante. Fotografia mesmo, não tinha. Havia desenho com bico de pena. Sabe uma fotografia que o Brasil ainda não tem? Pensei nisso quando me propus a fazer o livro. 
Paulo Boni - E com certeza ainda há muitas cenas das quais o Brasil não tem uma fotografia...

Pedro Martinelli - Tem, tem de monte. Um gateiro espetando uma onça com uma zagaia, por exemplo, eu nunca vi. Essa cena era comum no Estado de Mato Grosso, um sujeito com dois ou três cachorrinhos matava uma onça com uma zagaia, isso é incrível. Eu andei atrás de um gateiro para tentar fazer essa fotografia, mas os gateiros acabaram. Eu vi desenhos dessa cena em dezenas de livros. Aí pensei: eu quero fazer essa fotografia, quero contar essa história, quero conhecer o gateiro, como ele nasce, cresce, vive, onde mora, como é seu cotidiano. Então, eu planejei tudo e fui atrás. Quando eu voltava para São Paulo ia até a Livraria Cultura e via os livros sobre fotografias do Brasil, um festival de mesmices, carnaval, o passista rodando o pandeiro debaixo da bunda da baiana, pôr-do-sol e paisagens sempre iguais, eu ficava desanimado. Por outro lado, pensava: eu tenho que fazer um livro diferente. E pensava também que, para efeitos comerciais, o meu livro é feio, é em preto e branco, só tem caboclos. Mas hoje eu penso diferente. Penso que a saída é exatamente essa: mostrar um Brasil que o Brasil ainda não conhece. Contudo, hoje, um problema fundamental que você precisa levar em consideração é a segurança. $\mathrm{O}$ Brasil está tão violento que você não pode mais fotografar em segurança, a qualquer momento você pode ser assaltado, podem levar todo o seu equipamento, podem te matar. Não dá mais para você andar sozinho pelo Brasil, esse é o problema.

Paulo Boni - Infelizmente, essa é a dura e triste realidade...

Pedro Martinelli - Eu, por exemplo, quero muito trabalhar no Nordeste, lá tem vários lugares que eu quero fotografar, mas você vive inseguro, instável, sobressaltado. De manhã, você vai sair da pousadinha para viajar e o sujeito fala: "Moço, cuidado que tem muitos assaltos nessa região, a qualquer hora do dia". Recentemente eu estava no Pará filmando. Éramos uma equipe e estávamos de oito pessoas em uma van. Estávamos filmando em uma pequena reserva. Era uma comunidade simples, de acesso por uma estradinha de terra, um lugar maravilhoso. No final do dia, 
estávamos com todas as fitas, produzimos o dia inteiro. Aí, vira um caboclo e fala: "Tomem cuidado na saída, porque estão assaltando nesse trecho". Aquilo, na verdade, é uma arapuca, pois os gatunos marcam que você entrou e se preparam para te pegar na saída. Cara, é insegurança em todos os lugares. Às vezes você pensa estar no fim do mundo, e corre o risco de ser roubado. Então, você tem que contratar segurança, tem que colocar isso no orçamento, entendeu? Tem que colocar no item segurança uma caminhonete com dois caras armados para te escoltar, senão você corre o risco de perder tudo, todo o seu trabalho, entendeu?

Paulo Boni - E o equipamento também, é claro!

Pedro Martinelli - O equipamento é dramático. Você perder seu equipamento é trágico, mas acontece. Então, não dá mais para fazer mais nada, não dá mais para sair, não dá mais para andar. Os caras furam o pneu do seu carro e você é assaltado. Acabou, é inviável.

Paulo Boni -É triste, muito triste.

Pedro Martinelli - Mas, é a pura verdade. O cara te vê com uma câmera na mão, você sozinho, dando bandeira, ele vai armar para te roubar, encosta uma motinha do teu lado, te encosta uma arma e fala "passa tudo". Aí o cara te rouba tudo, o risco é enorme. Para mim, que normalmente trabalho sozinho, então, praticamente não dá mais, é impossível.

Paulo Boni - Vamos lá! Só mais duas perguntas e uma delas é um clichezão: como Pedro Martinelli definiria Pedro Martinelli?

Pedro Martinelli - Ah, não faço a menor ideia. Eu sou um caboclo do mato, nada mais que um mateiro.

Paulo Boni - Agora a última, a mais complicada na minha opinião: como você gostaria de ser lembrado?

Pedro Martinelli - Eu acho que eu fui um bom batedor de pernas, bati muita perna nessa vida. Continuo batendo perna. Quando o cara bate pernas, a missão está cumprida. Fotógrafo tem que pôr na cabeça que precisa bater perna, se não bater perna, não tem chapa. 
Paulo Boni - Tem lógica, muita lógica. Pedro, muitíssimo obrigado pela entrevista, pela simpatia, pela história de vida, pela cidadania, pela preocupação com um Brasil melhor e por sua luta pela fotografia.

Pedro Martinelli - Tá legal, um abraço. 